\title{
Entrepreneurial Capabilities of Women Entrepreneurs and Their Contributions to Entrepreneurship Development
}

\author{
Cesar P. Abasolo, MBA ${ }^{1}$, Gehana D. Lamug, DBA ${ }^{2}$ \\ ${ }^{1}$ Assistant Professor, Mabini Colleges, Inc. \\ ${ }^{2}$ Associate Professor, Camarines Norte State College
}

\begin{abstract}
Women play significant roles in entrepreneurship development in the country, particularly in the province of Camarines Norte. This study determined the entrepreneurial capabilities of women entrepreneurs and their contributions to entrepreneurship development in Camarines Norte. It employed a descriptive method of research in assessing the profile of women entrepreneurs; their entrepreneurial capabilities along identifying business opportunities, running a business, driving innovation and adapting to economic conditions; their contributions to entrepreneurship development and the problems commonly encountered by them.

Findings revealed that respondents mostly were 41 to 50 years old age bracket, married, with a baccalaureate degree, have been running the business for five to ten years as a small-type of enterprise, with an initial capital of P100,000 and below, and employed five and below employees. The entrepreneurial capabilities of women entrepreneurs were interpreted as much capable of identifying business opportunities, running a business, driving innovation, and adapting to economic conditions. The contributions of women entrepreneurs to entrepreneurship development were interpreted as much evident in terms of income generation, job creation, innovation, and environment protection. Also, the most common problem encountered by women entrepreneurs is business competition. Given the results of the study, a proposed training design was developed to help women entrepreneurs strengthen their entrepreneurial capabilities.
\end{abstract}

KEYWORDS: Entrepreneurial Capabilities, Entrepreneurship Development, Women Entrepreneurs

\section{INTRODUCTION}

Entrepreneurship is a multifaceted phenomenon, being analyzed as a process, a resource, or a state of being. Entrepreneurship development is the method of cultivating the abilities and understanding of entrepreneurs through several training programs. Its principal goal is to intensify the number of entrepreneurs, thereby increasing the speed of creating novel companies or enterprises. On a broader level, this will increase employment and improve the country's economy.

In almost all economies, women entrepreneurs are increasing significantly. With increasing sensitivity to social roles and economic conditions, women's hidden entrepreneurial potential has been growing. They play major roles in the community as they increase employment, boost entrepreneurial spirit, give opportunities to those with jobs but with low wages, minimize if not eradicate poverty, and exploit the maximum potential entrepreneurial capabilities.

In the Philippine setting, Bersales (2019), in her report issued to Philippine Statistics Authority found out that 56 percent of registered entrepreneurs are women as compared to men with 44 percent. In addition, the report emphasized that 54 percent of the trainings conducted by Department of Trade and Industry were attended by women as compared to men with 46 percent.

The increase in female entrepreneurs in the country is due to the implementation of Republic Act No. 7882, the main goal of which is to offer all probable support to Filipino women seeking to own, operate and manage small businesses. The promulgation of this law has encouraged more Filipino women to start businesses. Another law promulgated to promote the surge of women entrepreneurs is the Republic Act No. 9710, also identified as the Magna Carta for Women. Through this law, women seek to disregard bias by accepting, keeping, realizing and upholding the privileges of Filipino women, particularly those belonging to the marginalized classes of society.

The ideas and concepts related to women entrepreneurs have been widely researched for quite a long time. Comparing male and female entrepreneurs, factors affecting women entrepreneurs' performance, traits, competencies, and leadership of women 997 *Corresponding Author: Cesar P. Abasolo, MBA

Volume 04 Issue 08 August 2021

Available at: ijcsrr.org

Page No.-997-1007 


\section{International Journal of Current Science Research and Review}

ISSN: 2581-8341

Volume 04 Issue 08 August 2021

DOI: 10.47191/ijcsrr/V4-i8-17, Impact Factor: 5.825

IJCSRR@ 2021

www.ijesrr.org

entrepreneurs, its importance and contributions to the economy, and an essential tool of empowerment have been studied. Still, identifying the capabilities of women entrepreneurs and how they contribute to entrepreneurship development in a community where female entrepreneurs thrive has not been fully established in previous studies. To fill this gap, the present study analyzed the entrepreneurial capabilities of women entrepreneurs and their contributions to entrepreneurship development in Camarines Norte.

\section{METHODOLOGY}

This study utilized a descriptive method of research. According to Shields and Rangarajan (2013), descriptive analysis describes the characteristics of the population or phenomenon under study. Therefore, the descriptive research method was utilized because the study searched for answers about the profile of women entrepreneurs, entrepreneurial capabilities of women entrepreneurs, and their contributions to entrepreneurship development along identifying business opportunities, running a business, driving innovation, and adapting to economic conditions. Furthermore, it provided answers on the contributions of women entrepreneurs to entrepreneurship development in terms of income generation, job creation, innovation, and environmental protection.

\section{Description of the Respondents}

The respondents were the women entrepreneurs as the owners or operators of the enterprise. Their names were included in the Business Masterlist in 2018 in the Local Government Unit of Daet - Municipal Treasurer's Office. Lastly, the respondents' business location or address was in Daet, Camarines Norte. Most of the businesses owned and operated by women entrepreneurs were in line with food industry such as bakeries, catering, dried and fresh products, restaurants, resto bar; merchandising industry such as agricultural supplies, auto parts and supplies, bicycle and general merchandise, boutiques, surplus, school and office supplies; and service industry such as apartments and apartelles, hotels, beauty parlors, pharmacies, internet cafés, copy centers, pawnshops, spa massage services, building and space rentals.

\section{Statistical Treatment of Data}

The data gathered were classified, tabulated, organized, analyzed, and interpreted quantitatively as soon as retrieved. Descriptive statistics were used to analyze quantitative data. The study used various statistical tools, such as frequency counting and percentage techniques, to determine the profile of the respondents. Weighted mean was used to know the degree of entrepreneurial capabilities of women entrepreneurs along identifying business opportunities, running a business, driving innovation, and adapting to economic conditions. Moreover, ranking was used to determine the degree of contributions of women entrepreneurs to entrepreneurship development in terms of income generation, job creation, innovation, and environmental protection.

\section{RESULTS AND DISCUSSIONS}

On the respondents' profile, findings reveal that most of those surveyed were in between 41 to 50 years old, married, with baccalaureate degrees have been running the business for five to ten years as a small-type of enterprise, with an initial capital of P100,000 and below and employed five and below employees.

Tables 1 to 4 present the entrepreneurial capabilities of women entrepreneurs along identifying business opportunities, running a business, driving innovation, and adapting to economic conditions.

Identifying Business Opportunities. The result showed that the highest indicator in identifying business opportunities is listening to customers' needs and wants through interviews, feedbacks, evaluations and surveys with a mean score of 3.91 or interpreted as much capable. The lowest indicator is looking at industry new trends and insights through editorial reading of articles, magazines and newspapers with 3.54 mean score or interpreted as much capable.

Table 1. Entrepreneurial Capabilities of Women Entrepreneurs along Identifying Business Opportunities

\begin{tabular}{lll}
\hline \hline Indicators & WM & Adjectival Rating \\
\hline $\begin{array}{l}\text { 1. Listening to customer's needs and wants through interviews, } \\
\text { feedbacks, evaluations and surveys }\end{array}$ & MC \\
$\begin{array}{l}\text { 2. Seeing market demand and having potential idea to supply its } \\
\text { demand through deep observation and interviews }\end{array}$ & 3.60 & MC
\end{tabular}




\section{International Journal of Current Science Research and Review}

ISSN: 2581-8341

Volume 04 Issue 08 August 2021

DOI: 10.47191/ijcsrr/V4-i8-17, Impact Factor: 5.825

3. Looking at industry new trends and insights through editorial reading of articles, magazines and newspapers

$3.54 \quad$ MC

4. Spotting opportunity for a product/service that is being consumed in the market and its potential market through investigations and visual inspection

5. Examining the competition and potential competitive advantage for product/service by conducting industry surveys

6. Recognizing and responding to market changes such as competitor's move, technological evolution and revolution using thorough research and surveys

$3.80 \quad$ MC

$3.83 \quad \mathrm{MC}$

$3.64 \quad$ MC

$\begin{array}{lll}\text { Average Weighted Mean } & 3.72 & \text { MC }\end{array}$

\begin{tabular}{l}
\hline Legend: \\
$\quad 4.21-5.00$ Very Much Capable (VMC) \\
$3.41-4.20$ Much Capable $(M C)$ \\
$2.61-3.40$ Capable $(C)$
\end{tabular}

$1.81-2.60$ Less Capable (LC)

$1.01-1.80$ Not Capable (NC)

The result signifies that women entrepreneurs in Daet, Camarines Norte prefer to identify business opportunities through interviews, feedbacks, evaluations and surveys simply because they can get first-hand information from their potential customers on how they can improve their products and services, on how they will have better understanding of their needs and wants, and on how they will increase their satisfaction levels. Moreover, they will have time to analyze and think of best possible solutions to perform better. Similar with Jesnoewski (2018), which emphasized that listening to prospective customers will assist in the improvement or more customized products and Itani et al. (2019) that expressing concern toward customers by listening aids in attaining their needs.

Running a Business. The data revealed that the highest mean score of 4.03 is on managing time properly and orderly with an interpretation of very much capable. The indicator with the lowest mean score of 3.65 is on facing failures such as continuously experiencing low sales and negative profit with an interpretation of much capable.

Table 2. Entrepreneurial Capabilities of Women Entrepreneurs along Running a Business

\begin{tabular}{|c|c|c|}
\hline Indicators & 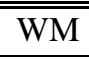 & "Adjectival Rating \\
\hline 1. Managing of time properly and orderly & 4.03 & $\mathrm{MC}$ \\
\hline 2. Hiring effective people thru proper training and managing them & 3.85 & $\mathrm{MC}$ \\
\hline $\begin{array}{l}\text { 3. Facing failures such as continuously experiencing low sales and negative } \\
\text { profit }\end{array}$ & 3.65 & MC \\
\hline $\begin{array}{l}\text { 4. Building good relationships positively through networking such as } \\
\text { suppliers, potential investors, customers and employees }\end{array}$ & 3.92 & $\mathrm{MC}$ \\
\hline $\begin{array}{l}\text { 5. Building good relationships with government and non-government offices } \\
\text { and agencies }\end{array}$ & 3.80 & $\mathrm{MC}$ \\
\hline $\begin{array}{l}\text { 6. Seeking government and non-government grant and support to raise } \\
\text { additional investment }\end{array}$ & 3.71 & $\mathrm{MC}$ \\
\hline Average Weighted Mean & 3.83 & $\mathrm{MC}$ \\
\hline
\end{tabular}
Legend:

$4.21-5.00$ Very Much Capable (VMC)

$1.81-2.60$ Less Capable (LC)

$3.41-4.20$ Much Capable (MC)

$1.01-1.80$ Not Capable (NC)

$2.61-3.40$ Capable $(C)$ 


\section{International Journal of Current Science Research and Review}

ISSN: 2581-8341

Volume 04 Issue 08 August 2021

DOI: 10.47191/ijcsrr/V4-i8-17, Impact Factor: 5.825

IJCSRR@ 2021

Www.ijcsrr.org

The result shows that for an entrepreneur, time is of essence. Hence, as women entrepreneurs are good in balancing their lives as mothers, as wives, as daughters, and as individuals. They know how to delegate responsibilities for them to have their personal time. Women entrepreneurs multitask effectively by using their time properly. They seldom miss deadlines, meetings and targets as they trained themselves in managing the the demands of work and family. It is corroborated by Mukthar and Faiz (2020) which found out women entrepreneurs experience varied level of work-life instability, and provide active strategies to withstand this challenge, while Peshev (2017) emphasized that as entrepreneurs, they have to balance different duties, answer calls, participate in activities, and be extra careful with every decision.

Driving Innovation. The data shows that the indicator with the highest mean score of 4.03 is searching opportunities to do new things interpreted as very much capable; while the indicator with the lowest mean score of 3.66 is recognizing and appreciating workers' abilities to solve problems on their own interpreted as much capable.

Table 3. Entrepreneurial Capabilities of Women Entrepreneurs along Driving Innovation

\begin{tabular}{lll}
\hline \multicolumn{1}{c}{ Indicators } & WM & Adjectival Rating \\
\hline $\begin{array}{l}\text { 1. Searching opportunities to do new things } \\
\begin{array}{l}\text { 2. Enhancing traditional products to much more attractive and competitive products } \\
\text { through continuous product development. }\end{array}\end{array}$ & 4.03 & MC \\
$\begin{array}{l}\text { 3. Embracing new tools and techniques available to improve the products/services } \\
\text { offered }\end{array}$ & 3.75 & MC \\
$\begin{array}{l}\text { 4. Seeking solution for the development of new products through technological } \\
\text { knowledge }\end{array}$ & 3.98 & MC \\
$\begin{array}{l}\text { 5. Implementing innovation policies strategies through human capital development } \\
\text { like trainings and seminars }\end{array}$ & 3.87 & MC \\
$\begin{array}{l}\text { 6. Recognizing and appreciating workers abilities to solve problems on their own } \\
\text { Average Weighted Mean }\end{array}$ & 3.66 & MC \\
\hline \hline
\end{tabular}

Legend:

4.21 - 5.00 Very Much Capable (VMC)

$1.81-2.60$ Less Capable (LC)

$3.41-4.20$ Much Capable (MC)

$1.01-1.80$ Not Capable (NC)

$2.61-3.40$ Capable $(C)$

The result implies that the women entrepreneurs search for opportunities in order to do new things. Moreover, through innovation they effectively respond to unforeseen events, meet technology advancements, respond to increasing customer expectations and choices, and easily adapt to trends. Most of the women entrepreneurs buy new equipment to speed up their service effectively and produce more products to meet customer needs and demands. Some women entrepreneurs find new techniques and processes to improve their service by attending seminars and conferences such as attending business expo and trade fares. Women entrepreneurs who are participating in the latter increase business connections and learn new ways to improve products and services. These women entrepreneurs want to find new opportunities for them to offer something new to customers that can be an advantage to their competitors. As exemplified by Manolova et al. (2020) women entrepreneurs execute opportunity seeking by concentrating on their actual resources and capacities and distinguishing ways to convert it to new ones. In addition, Satara (2019) emphasized that looking for opportunities in the market and prioritizing knowledge learned are the two reasons why entrepreneurs should always be open to new possibilities.

Adopting to Economic Conditions. The data in Table 4 revealed that the indicator with the highest mean score of 4.04 is adjusting easily to changes such as change in government rules and regulations, tax implementations, and administrations with an interpretation of very much capable; while the indicator with the lowest mean score of 3.76 is intervening collective bargaining agreement issues like wage increase, rank and file working conditions, benefits, and stability of tenure with much capable interpretation. 


\section{International Journal of Current Science Research and Review}

ISSN: 2581-8341

Volume 04 Issue 08 August 2021

DOI: 10.47191/ijesrr/V4-i8-17, Impact Factor: 5.825

IJCSRR@ 2021

www.ijesrr.org

Table 4. Entrepreneurial Capabilities of Women Entrepreneurs along Adopting to Economic Conditions

\begin{tabular}{lll}
\hline \hline \multicolumn{1}{c}{ Indicators } & WM & Adjectival Rating \\
\hline $\begin{array}{l}\text { 1. Adjusting easily to changes such as change in government rules and } \\
\text { regulations, tax implementations, and administrations }\end{array}$ & 4.04 & $\mathrm{MC}$ \\
$\begin{array}{l}\text { 2. Seeing the positives in the face of challenges such as creating opportunities } \\
\text { during inflation and recession }\end{array}$ & 3.89 & $\mathrm{MC}$ \\
$\begin{array}{l}\text { 3. Willing to be flexible and has a determination to succeed during economic } \\
\text { declines }\end{array}$ & 3.78 & $\mathrm{MC}$ \\
$\begin{array}{l}\text { 4. Being calm and focused in times of economic downturns } \\
\text { 5. Facilitating labor issues like rallies, strikes, unions, and lock-out }\end{array}$ & 3.90 & $\mathrm{MC}$ \\
$\begin{array}{l}\text { 6. Intervening collective bargaining agreement issues like wage increase, rank } \\
\text { and file working conditions, benefits, and stability of tenure }\end{array}$ & 3.76 & $\mathrm{MC}$ \\
Average Weighted Mean & & $\mathrm{MC}$ \\
\hline \hline
\end{tabular}

Legend:

$\begin{array}{ll}4.21-5.00 \text { Very Much Capable }(V M C) & 1.81-2.60 \text { Less Capable }(L C) \\ 3.41-4.20 \text { Much Capable }(M C) & 1.01-1.80 \text { Not Capable }(N C) \\ 2.61-3.40 \text { Capable }(C) & \end{array}$

The result implies that women entrepreneurs are very much capable to adjust to changes in any economic conditions. It denotes that if any changes occur, women entrepreneurs can adjust at once and think of ways to solve problems. As the women entrepreneurs adapt to rapidly changing business environment, they become aware of the situation, they understand the change, and momentarily, it builds their skills and knowledge to overcome the change easily. Saini and Jain (2018) pointed out that women of the 21 st century have the capability to change economies into flourishing organizations. Furthermore, Sammon (2019), women entrepreneurs should discover steps to foresee and change their ways of thinking.

Tables 5 to 8 present the contributions of women entrepreneurs to entrepreneurship development in terms of income generation, job creation, innovation, and environmental protection.

Income Generation. The data in Table 5 revealed that the indicator with the highest mean score of 4.02 is business expansion with an interpretation of very much evident; while the indicator with the lowest mean score of 3.80 is compliant to government rules and regulations with much evident as its interpretation.

Table 5. Contributions of Women Entrepreneurs to Entrepreneurship Development in terms of Income Generation

\begin{tabular}{lcc}
\hline \hline \multicolumn{1}{c}{ Indicators } & WM & Adjectival Rating \\
\hline $\begin{array}{l}\text { 1. Equity to employee (if hired, employees can afford to buy their basic } \\
\text { commodities out of their income from the company) }\end{array}$ & ME \\
$\begin{array}{l}\text { 2. Effective use of resources (full utilization of available resources without } \\
\text { any wastage) }\end{array}$ & 3.82 & ME \\
$\begin{array}{l}\text { 3. Compliant to government rules and regulations (paying taxes and } \\
\text { necessary licenses and permits) }\end{array}$ & ME \\
$\begin{array}{l}\text { 4. Business expansion (has potential to open another branch in another } \\
\text { location) }\end{array}$ & ME \\
$\begin{array}{l}\text { 5. Provision of sustainable products and services (products and services are } \\
\text { always available at any time in a proper place) }\end{array}$ & 3.95 & $\mathrm{ME}$ \\
Average Weighted Mean & 3.92 & $\mathrm{ME}$ \\
\hline \hline
\end{tabular}




\section{International Journal of Current Science Research and Review}

ISSN: 2581-8341

Volume 04 Issue 08 August 2021

DOI: 10.47191/ijesrr/V4-i8-17, Impact Factor: 5.825

IJCSRR@ 2021

www.ijesrr.org

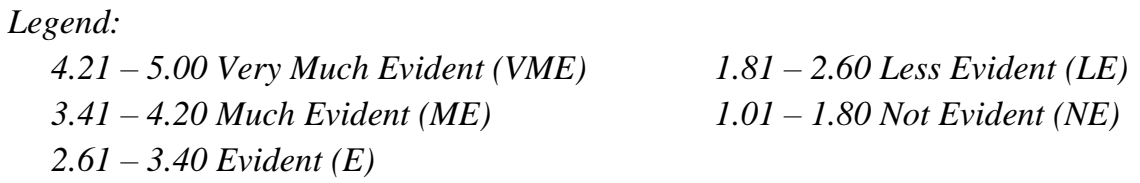

The findings shows that women entrepreneurs in Daet, Camarines Norte contribute very much evidently in the entrepreneurial development, for they are looking forward to expanding businesses in the near future. These women entrepreneurs want to make their businesses grow and expand, for it signifies success and can contribute to entrepreneurship development. Similar with Anggadwita et al. (2017) wherein women entrepreneurs are thriving and contributory to important economic activities and they trim down unemployment rates. According to Ward (2019) learning how to expand business is not just a commendable goal but it is essential for a firm's survival and economic well-being.

Job Creation. The data in Table 6 revealed that the indicator with the highest mean score of 4.20 is compliant to gender and development with an interpretation of very much evident; while the indicator with the lowest mean score of 3.70 is personal growth with much evident as its interpretation.

Table 6. Contributions of Women Entrepreneurs to Entrepreneurship Development in terms of Job Creation

\begin{tabular}{|c|c|c|}
\hline Indicators & WM & Adjectival Rating \\
\hline $\begin{array}{l}\text { 1. Compliant to gender and development (hire employees without any } \\
\text { gender discrimination) }\end{array}$ & 4.20 & ME \\
\hline $\begin{array}{l}\text { 2. Provision of benefits, incentives and rewards (giving what is due to } \\
\text { employees, following contract agreements) }\end{array}$ & 3.90 & ME \\
\hline 3. Personal growth (has room for promotion and advancements) & 3.70 & $\mathrm{ME}$ \\
\hline $\begin{array}{l}\text { 4. Possible opportunity for career growth (send to seminar-workshops, } \\
\text { trainings and conferences) }\end{array}$ & 3.98 & ME \\
\hline $\begin{array}{l}\text { 5. Appropriate job placement (skills are utilized to its full potential } \\
\text { because they are satisfied and contended with their work) }\end{array}$ & 4.05 & ME \\
\hline Average Weighted Mean & 3.97 & ME \\
\hline \multicolumn{3}{|l|}{ Legend: } \\
\hline $4.21-5.00$ Very Much Evident (VME) & \multirow{3}{*}{\multicolumn{2}{|c|}{$\begin{array}{l}1.81-2.60 \text { Less Evident }(L E) \\
1.01-1.80 \text { Not Evident }(N E)\end{array}$}} \\
\hline $3.41-4.20$ Much Evident $(M E)$ & & \\
\hline $2.61-3.40$ Evident $(E)$ & & \\
\hline
\end{tabular}

The result shows that most of the women entrepreneurs are compliant to gender and development, wherein they hire employees regardless of their gender preferences. Most women entrepreneurs give equal opportunities to all types of individuals. They employ without gender discrimination. These women entrepreneurs do not mind if they employ such as long as they will do their duties and responsibilities well.

Innovation. The data in Table 7 revealed that the indicator with the highest mean score of 4.12 is adoption of new technologies with an interpretation of very much evident; while the indicator with the lowest mean score of 3.77 is cost-efficient and cost-effective with much evident as its interpretation.

Table 7. Contributions of Women Entrepreneurs to Entrepreneurship Development in terms of Innovation

\begin{tabular}{lcc}
\hline \hline Indicators & WM & Adjectival Rating \\
\hline $\begin{array}{l}\text { 1. Adoption of new technologies (can adopt based on the industry needs to } \\
\text { provide ease of operation) }\end{array}$ & 4.12 & ME
\end{tabular}




\section{International Journal of Current Science Research and Review}

ISSN: 2581-8341

Volume 04 Issue 08 August 2021

DOI: 10.47191/ijesrr/V4-i8-17, Impact Factor: 5.825

IJCSRR@ 2021

www.ijesrr.org

2. Implementation of new ideas and processes (can adopt new skills, tools or knowledge to ease the operation)

3. Cost-efficient and cost-effective (product offerings rendered are economical)

4. Competitive offerings (product offerings has variety or choices)

3.77

ME

5. Generates greater output (implementing technologies or processes that are needed to make more products)

$\mathrm{ME}$

$\mathrm{ME}$

$3.98 \quad \mathrm{ME}$

Average Weighted Mean

3.94

$\mathrm{ME}$

\begin{tabular}{ll}
\hline \hline Legend: & \\
& \\
$4.21-5.00$ Very Much Evident $(V M E)$ & $1.81-2.60$ Less Evident $(L E)$ \\
$3.41-4.20$ Much Evident $(M E)$ & $1.01-1.80$ Not Evident $(N E)$ \\
$2.61-3.40$ Evident $(E)$ &
\end{tabular}

The findings shows that most of the women entrepreneurs in Daet, Camarines Norte adopt new technologies to ease their operations. Most of them attend and participate in business expo initiated and conducted by DTI to showcase their products and at the same time look for new techniques or technology that can give them competitive advantage over other competitors and can save money in the long-run. Taking advantage of technology has led to major changes in the way small businesses operate; an example of this is using the power of social media. These women entrepreneurs are using them to reach out to potential customers in greater numbers. They also used the online advertising. Like what Lokal Delivery Service and Daet Pabili Delivery Services are doing, they use Facebook as their marketing platform. Consumers can have their needs and wants in just a few minutes with an additional service charge. According to Muhammed (2018) it is essential for business owners to keep up with new technologies, technological trends.

Environmental Protection. The data in Table 8 revealed that the indicator with the highest mean score of 4.13 is compliant to legal obligations with an interpretation of very much evident; while the indicator with the lowest mean score of 3.70 is tolerable effects to environment with much evident as its interpretation.

Table 8. Contributions of Women Entrepreneurs to Entrepreneurship Development in terms of Environmental Protection

\begin{tabular}{lcc}
\hline \hline \multicolumn{1}{c}{ Indicators } & WM & Adjectival Rating \\
\hline $\begin{array}{l}\text { 1. Compliant to legal obligations (compliance to local government } \\
\text { agencies) }\end{array}$ & ME \\
$\begin{array}{l}\text { 2. Products/services are environment friendly (use of biodegradable } \\
\text { packaging) }\end{array}$ & 3.80 & ME \\
$\begin{array}{l}\text { 3. Tolerable effects to environment (products' waste has acceptable effect } \\
\text { to environment) }\end{array}$ & 3.70 & ME \\
$\begin{array}{l}\text { 4. Lesser effects to climate change (packaging materials used has low } \\
\text { threat to environment) }\end{array}$ & ME \\
$\begin{array}{l}\text { 5. Organization has internal policies regarding proper waste disposal (like } \\
\text { recycling, reducing and reusing) }\end{array}$ & 4.06 & ME \\
Average Weighted Mean & 3.91 & ME \\
\hline \hline
\end{tabular}

Legend:

$\begin{array}{ll}4.21-5.00 \text { Very Much Evident }(V M E) & 1.81-2.60 \text { Less Evident }(L E) \\ 3.41-4.20 \text { Much Evident }(M E) & 1.01-1.80 \text { Not Evident }(N E) \\ 2.61-3.40 \text { Evident }(E) & \end{array}$




\section{International Journal of Current Science Research and Review}

ISSN: 2581-8341

Volume 04 Issue 08 August 2021

DOI: 10.47191/ijcsrr/V4-i8-17, Impact Factor: 5.825

IJCSRR@ 2021

www.ijesrr.org

The result shows that most of the women entrepreneurs are compliant to all legal obligations. Although, the result in Table 5 shows that being compliant to government rules and regulations along income generations is the lowest in terms of mean score as, it also shows that women entrepreneurs can still manage to process the necessary documents needed for them to operate legally. Ashe-Edmunds (2018) expressed that understanding the reasons on the enactment of business policies and regulations will helpthe firm in the long run and able to get the benefits of being compliant at all times.

\section{Problems Encountered by Women Entrepreneurs in Enhancing their Entrepreneurial Capabilities}

Table 9 shows that business competition is their main or top problem which is followed by collections of receivables, and high cost of operation. Moreover, friction with husband's role in the family, conflicts of interest on mission of the business and working closely with sectors in the community are lowest in rank.

Table 9. Problems Encountered by Women Entrepreneurs in Enhancing their Entrepreneurial Capabilities

\begin{tabular}{lll}
\hline \hline Indicators & Frequency & Rank \\
\hline 1. Collections of receivables & 99 & 2 \\
2. Business competition & 230 & 1 \\
3. High cost of operation & 90 & 3 \\
4. Government regulations & 89 & 4 \\
5. High lending interest rate by banks & 25 & 11 \\
6. Professional rivalry & 22 & 12 \\
7. Lack of training and orientation on business management & 51 & 6 \\
8. Wrong choice of education degree to present career & 34 & 10 \\
9. Less time spent with husband and children & 47 & 8 \\
10. No time for house keeping & 67 & 5 \\
11. Conflict between work and family matters & 39 & 9 \\
12. Friction with husband role in the family & 20 & 13 \\
13. No time for social or family gatherings & 50 & 7 \\
14. Working closely with sectors in the community & 11 & 15 \\
15. Conflicts of interest on mission of the business & 19 & 14 \\
\hline \hline
\end{tabular}

The respondents perceived that business competition is their main problem in enhancing their entrepreneurial capabilities. The negative perception about competition can make the enterprises more competitive by offering new or better products, more efficient processes, and adding more value to their products or services, thus, making it more beneficial to consumers and end-users. Similarly, Zhu et al. (2018) found out that hyper competition is one of the challenges of women entrepreneurs in China and Vietnam. According to Garstenstein (2018) competition is a reality of life for any business organization.

\section{Proposed Training Design to Strengthen Entrepreneurial Capabilities of Women Entrepreneurs}

The proposed training design is not only based on the problems encountered by women entrepreneurs. It is also based on what the researcher considers in strengthening women's entrepreneurial capabilities. Therefore, it can monitor and evaluate what improvements are still needed by women entrepreneurs. The training is designed for women entrepreneurs, owners, millennials who aspire to be entrepreneurs, housewives, and BS in Entrepreneurship students. The institution will initiate a partnership with local government offices such as the Department of Trade and Industry, Technical Education and Skills Development Authority (TESDA), Barangay Local Government Units, and local government units. 
ISSN: 2581-8341

Volume 04 Issue 08 August 2021

DOI: 10.47191/ijcsrr/V4-i8-17, Impact Factor: 5.825

Table 10. Proposed Training Design for Local Entrepreneurs

\begin{tabular}{|c|c|c|c|c|c|}
\hline $\begin{array}{l}\text { Training Content / } \\
\text { Project Components }\end{array}$ & Learning Objectives & Approach & $\begin{array}{l}\text { Learning } \\
\text { Method }\end{array}$ & $\begin{array}{l}\text { Persons } \\
\text { Involved } \\
\text { Facilitator }\end{array}$ & $\begin{array}{l}\text { Target } \\
\text { Date }\end{array}$ \\
\hline 1. Governance & $\begin{array}{l}\text { To secure the rights of women } \\
\text { entrepreneur and give the } \\
\text { support that they need } \\
\text { To enable women entrepreneurs } \\
\text { generate capital through } \\
\text { financial aid given by NGOs } \\
\text { To assist women entrepreneurs } \\
\text { in receiving fast registration of } \\
\text { their business }\end{array}$ & $\begin{array}{l}\text { Law } \\
\text { implementation } \\
\text { Financial aid } \\
\text { program } \\
\text { Process } \\
\text { checking }\end{array}$ & $\begin{array}{l}\text { Lecture, } \\
\text { discussion, } \\
\text { interpretation } \\
\text { with } \\
\text { demonstration }\end{array}$ & $\begin{array}{l}\text { BLGU, } \\
\text { MLGU, \& } \\
\text { CNSC } \\
\text { Graduate } \\
\text { School } \\
\text { Faculty, } \\
\text { support staff } \\
\text { Students and } \\
\text { other } \\
\text { stakeholders. }\end{array}$ & $\begin{array}{l}2020- \\
\text { onwards }\end{array}$ \\
\hline $\begin{array}{ll}\text { 2. } & \text { Marketing and } \\
& \text { Entrepreneurship }\end{array}$ & $\begin{array}{l}\text { To give way for product } \\
\text { competitiveness enhancement } \\
\text { and increase in trade investment } \\
\text { opportunities } \\
\text { To help women entrepreneurs } \\
\text { sell their products in good } \\
\text { market conditions }\end{array}$ & $\begin{array}{l}\text { Business linkage } \\
\text { program } \\
\\
\text { Market } \\
\text { positioning }\end{array}$ & $\begin{array}{l}\text { Lecture, } \\
\text { discussion, } \\
\text { interpretation } \\
\text { with } \\
\text { demonstration }\end{array}$ & $\begin{array}{l}\text { DTI \& CNSC } \\
\text { Graduate } \\
\text { School } \\
\text { Faculty, } \\
\text { support staff } \\
\text { Students and } \\
\text { other } \\
\text { stakeholders. }\end{array}$ & $\begin{array}{l}2020- \\
\text { onwards }\end{array}$ \\
\hline $\begin{array}{l}\text { 3. Information, } \\
\text { Dissemination \& } \\
\text { Education }\end{array}$ & $\begin{array}{l}\text { To enable women entrepreneurs } \\
\text { fully understand business } \\
\text { policies and their implementing } \\
\text { guidelines } \\
\text { To help women entrepreneur } \\
\text { sustain and fully develop their } \\
\text { business } \\
\text { To enhance the skills and } \\
\text { capabilities of women } \\
\text { entrepreneurs in terms of } \\
\text { entrepreneurial activity }\end{array}$ & $\begin{array}{l}\text { Seminar } \\
\text { Philippine } \\
\text { Commission on } \\
\text { Women and } \\
\text { Gender } \\
\text { Responsive } \\
\text { Actions for the } \\
\text { Transformation } \\
\text { of Women } \\
\text { Information and } \\
\text { dissemination }\end{array}$ & $\begin{array}{l}\text { Lecture, } \\
\text { discussion, } \\
\text { interpretation } \\
\text { with } \\
\text { demonstration }\end{array}$ & $\begin{array}{l}\text { DTI \& CNSC } \\
\text { Graduate } \\
\text { School } \\
\text { Faculty, } \\
\text { support staff } \\
\text { Students and } \\
\text { other } \\
\text { stakeholders. }\end{array}$ & $\begin{array}{l}2020- \\
\text { onwards }\end{array}$ \\
\hline
\end{tabular}




\section{International Journal of Current Science Research and Review}

ISSN: 2581-8341

Volume 04 Issue 08 August 2021

DOI: 10.47191/ijcsrr/V4-i8-17, Impact Factor: 5.825

IJCSRR@ 2021

Www.ijcsrr.org

\begin{tabular}{|c|c|c|c|c|c|}
\hline $\begin{array}{ll}\text { 4. } & \text { Entrepreneurship } \\
\text { Training }\end{array}$ & $\begin{array}{l}\text { To improve livelihood of Urban } \\
\text { and Rural areas specifically poor } \\
\text { women and increase the number } \\
\text { of women engaging in } \\
\text { entrepreneurial activity } \\
\text { To develop skills of Filipino } \\
\text { women entrepreneurs in terms of } \\
\text { product development and } \\
\text { product innovation }\end{array}$ & $\begin{array}{l}\text { Technical- } \\
\text { Vocational } \\
\text { Education } \\
\text { Program in } \\
\text { coordination } \\
\text { with TESDA } \\
\\
\text { Entrepreneurship } \\
\text { trainings }\end{array}$ & $\begin{array}{l}\text { Lecture, } \\
\text { discussion, } \\
\text { interpretation } \\
\text { with } \\
\text { demonstration }\end{array}$ & $\begin{array}{l}\text { TESDA \& } \\
\text { CNSC } \\
\text { Graduate } \\
\text { School } \\
\text { Faculty, } \\
\text { support staff } \\
\text { Students and } \\
\text { other } \\
\text { stakeholders. }\end{array}$ & $\begin{array}{l}2020 \\
\text { onwards }\end{array}$ \\
\hline
\end{tabular}

The proposed training design aims to improve livelihood of poor women and increase the number of women engaging in entrepreneurial activity, help sell their products in good market conditions and assist in securing fast registration of their business. It intends to fully understand business policies and implementing guidelines, enable them to generate capital through financial aid given by non-government organization, sustain and fully develop their business, secure their rights and give the support they need.

In the implementation of the said training design, it is expected that women entrepreneurs will increase in number, will improve their way of living, will have an access in market place wherein they can sell their products efficiently, be more informed regarding business policies and guidelines, have more sustainable and empowered individual and a well-protected women entrepreneurs receiving equal rights inside and outside business environment.

\section{CONCLUSIONS}

The entrepreneurial capabilities of women entrepreneurs were all interpreted as much capable along identifying business opportunities, running a business, driving innovation, and adopting to economic conditions. The women entrepreneurs in Daet, Camarines Norte identified business opportunities through interviews, feedbacks, evaluations and surveys, managing time properly and orderly, searching opportunities to do new things and adjusting easily to changes. The contributions of women entrepreneurs to entrepreneurship development were much evident in terms of income generation through business expansion, job creation by being compliant to gender and development initiatives, innovation through adoption of new technologies, and environmental protection by being compliant to legal obligations. Business competition was the most common problem women entrepreneurs encountered. Considering the results of the study, women entrepreneurs may consider enhancing their capabilities through exposure to various capacity-building opportunities provided by the government and other relevant agencies.

\section{REFERENCES}

1. Bersales, LG. S. (2019). PSA Issues Updates on Women and Men in the Philippines Reference No.: 2019-029. https://psa.gov.ph/gender-stat.

2. Republic Act 7882. An Act Providing Assistance to Women Engaging in Micro and Cottage Business Enterprises and for Other Purposes. https://pcw.gov.ph/republic-act-7882-provision-of-assistance-to-women-engaging-in-micro-and-cottagebusiness-enterprises-and-for-other-purposes/

3. Republic Act 9710. Magna Carta of Women. https://www.officialgazette.gov.ph/2009/08/14/republic-act-no-9710/

4. Shields, P. \& Rangarajan, N. (2013). A Playbook for Research Methods: Integrating Conceptual Frameworks and Project Management. https://www.semanticscholar.org/paper/A-Playbook-for-Research-Methods\%3A-Integrating-and-ShieldsRangarajan/854b292ee68cbd18fb4e7dec1fe2e88ccd4dad5f

5. Jesnoewski, A. (2018). Four ways to identify more business opportunities. smartcompany: https://www.smartcompany.com.au/startupsmart/advice/business-planning/four-ways-to-identify-more-businessopportunities/. 


\section{International Journal of Current Science Research and Review}

ISSN: 2581-8341

Volume 04 Issue 08 August 2021

DOI: 10.47191/ijesrr/V4-i8-17, Impact Factor: 5.825

IJCSRR @ 2021

Www.ijcsrr.org

6. Itani, O. S., Goad, E. A., \& Jaramillo, F. (2019). Building customer relationships while achieving sales performance results: Is listening the holy grail of sales?. Journal of Business Research, 102, 120-130. https://www.sciencedirect.com/science/article/abs/pii/S0148296319303017

7. Mukhtar, A., \& Faiz, R. (2020). Fighting Work-Life Conflict: Strategies of Women Entrepreneurs of Fashion Industry of Pakistan. Business \& Economic Review, 12(4), 44-70. http://bereview.pk/index.php/BER/article/view/358

8. Peshev, M. (2019). 8 Things Entrepreneurs Need to Know About Running a Business and Landing Customers. https://mariopeshev.com/entrepreneurship/8-things-entrepreneurs-need-running-business-landing-customers/.

9. Manolova, T. S., Brush, C. G., Edelman, L. F., \& Elam, A. (2020). <? covid19?> Pivoting to stay the course: How women entrepreneurs take advantage of opportunities created by the COVID-19 pandemic. International Small Business Journal, 38(6), 481-491. https://journals.sagepub.com/doi/full/10.1177/0266242620949136

10. Satara, A. (2019). 2 Reasons Entrepreneurs Should Always Be Open to New Opportunities. https://www.inc.com/alyssasatara/why-entrepreneurs-should-constantly-be-searching-for-new-opportunities-even-while-running-a-successfulcompany.html.

11. Saini, K., \& Jain, S. (2018). Women Entrepreneurship The Emerging Workforce in 21st Century: Turning Challenges into Opportunities. International Journal of Research in Management \& Social Science, 101.

https://www.researchgate.net/profile/Lekha-

Ravi/publication/335772906_Volume_6_Issue_2_IV_public_private_partnership_ppp_in_infrastructure_developmenta_cr itical_review_lekha_ravi_and_dr_p_g_arul/links/5d7a43de299bf1cb809b40ba/volume-6-issue-2-iv-public-privatepartnership-ppp-in-infrastructure-development-a-critical-review-Lekha-Ravi-and-Dr-P-G-Arul.pdf\#page=108

12. Sammon, D. (2019). 7 Tips For Entrepreneurs To Adapt To Changes In Business. https://thriveglobal.com/stories/7-tipsfor-entrepreneurs-to-adapt-to-changes-in-business/.

13. Anggadwita, G., Luturlean, B. S., Ramadani, V., \& Ratten, V. (2017). Socio-cultural environments and emerging economy entrepreneurship: Women entrepreneurs in Indonesia. Journal of Entrepreneurship in Emerging Economies. https://www.emerald.com/insight/content/doi/10.1108/JEEE-03-2016-0011/full/html

14. Ward, S. (2019). How to Transform Your Small Business Into a Big Business.https://www.thebalancesmb.com/top-waysof-growing-your-business-2948140.

15. Muhammed, A. (2018). Why Entrepreneurs Should Keep Up With New Technologies. https://www.entrepreneur.com/article/316042.

16. Ashe-Edmunds, S. (2018). Importance of Compliance in Business. https://smallbusiness.chron.com/importancecompliance-business-71173.html.

17. Zhu, L., Kara, O., \& Zhu, X. (2019). A comparative study of women entrepreneurship in transitional economies: The case of China and Vietnam. Journal of Entrepreneurship in Emerging Economies. https://www.emerald.com/insight/content/doi/10.1108/JEEE-04-2017-0027/full/html

18. Garstenstein, D. (2018). What Are the Advantages \& Disadvantages of Economic Competition?.https://bizfluent.com/info8455003-advantages-disadvantages-economic-competition.html.

Cite this Article: Cesar P. Abasolo, MBA, Gehana D. Lamug, DBA (2021). Entrepreneurial Capabilities of Women Entrepreneurs and Their Contributions to Entrepreneurship Developmenty. International Journal of Current Science Research and Review, 4(8), 997-1007 